\title{
PERISTILAHAN ADAT PERNIKAHAN PADA MASYARAKAT MADURA DI WAJOK HILIR, KABUPATEN MEMPAWAH
}

\author{
Suhardi, Ahmad Rabi'ul Muzammil, Agus Syahrani \\ Program Studi Pendidikan Bahasa dan Sastra Indonesia \\ FKIP Untan Pontianak \\ Email:suhardifkip8@gmail.com
}

\begin{abstract}
The study of the Madurese Traditional Marriage Terminology in Mempawah in WajokHilir Village has three traditional processions that must be carried out by the bride and groom and their families. First, the pre-wedding procession which consists of five traditional processes that must be carried out, namely; (1) ngangane, (2) arabe fence, (3) nyabe' snack, (4) teketpetton, and (5) nyedektemo. After carrying out the pre-wedding rituals or traditional traditions, the second procession is followed by a wedding procession. In the wedding procession, there are four traditional processions that the bride and groom must undergo, namely; (1) arepbe, (2) bereskoneng, (3) contract, and (4) delivery of the weakest delivery. Then the third or final procession is the post-wedding procession. In the postwedding procession, the bride and groom are required to carry out the traditional cenglanceng ritual, the ritual is a closing ritual. In the cenglanceng ritual, the bride and groom carry out a slametan procession or salvation for the marriage that has been carried out and hope that the marriage can get safety and happiness in building a household.
\end{abstract}

\section{Keywords: Terminology, wedding, Madura community,}

\section{PENDAHULUAN}

Indonesia adalah negara yang memiliki kebudayaan yang beraneka ragam yang tersebar dari Sabang sampai Marauke. Kekayaan yang dimiliki oleh masyarakat Indonesia tersebut tidak hanya berupa kekayaan sumber alam saja, tetapi masyarakat Indonesia juga memiliki kekayaan lain seperti kekayaan akan kebudayaan suku bangsa Indonesia yang tersebar di seluruh kepulauan Indonesia.

Upacara perkawinan di Indonesia ialah upacara yang dikira sangat sakral serta diselenggarakan secara meriah serta terencana disesuaikan dengan tradisinya.

Dalam adat warga Madura di Mempawah, tahapan perkawinan diawali dengan kegiatan lamaran. Pada upacara perkawinan, umumnya kedua mempelai dirias berbusana secara spesial. Berbeda apa yang mereka gunakan pada pesta- pesta resepsi tiap hari. Tata rias serta busana pengantin jadi pusat atensi warga serta spesialnya menarik atensi para tamu yang muncul dalam acara itu. Oleh sebab itu, perihal yang demikian itu nyatanya pula dicoba oleh suku Madura pada biasanya. Bersumber pada keyakinan terhadap nenek moyang serta leluhar yang mendahului.

Adat berasal dari kata bahasa Arab yang berarti“" Kerutinan”, jadi secara etimologi adat bisa dimaksud selaku perbuatan yang dicoba dengan berulangulang kemudian jadi sesuatu Kerutinan yang senantiasa dihormati orang, hingga Kerutinan jadi adat.

Adat merupakan sesuatu Kerutinan yang berkembang serta tercipta dalam sesuatu warga ataupun wilayah yang dikira berharga, dipelihara, serta disubordinasikan kepada warga. Contohnya tercantum bea 
cukai, seni serta properti. Jadi Kerutinan bukan berarti wajib diterima, dihargai, dihayati, serta dipertahankan hingga mati. Adat yang diterima hendak jadi faktor yang hidup dalam kehidupan pemeluknya. Dia jadi bagian dari masa kemudian, masih dilestarikan, serta menempati tempat yang sama dengan inovasi- inovasi baru. Adat merupakan cerminan panjang tentang perilaku serta sikap manusia, yang dilakukan secara turun- temurun, diawali dari nenek moyang kita.

Adat istiadat yang mengakar akan menjadi sumber watak dan watak. Adat, atau adat, dalam pengertian yang paling sederhana, telah dipraktikkan sejak lama dan merupakan bagian dari kehidupan kelompok masyarakat yang sama. Hal terpenting dalam adat adalah adanya informasi yang diturunkan dari generasi ke generasi, baik secara tertulis maupun lisan. Karena tanpa ini, adat bisa hilang.

Adat juga dapat diartikan dalam masyarakat manusia sebagai kebiasaan umum yang secara otomatis mempengaruhi perilaku dan reaksi dalam kehidupan sehari-hari anggota masyarakat itu. Perkawinan bagi masyarakat Madura bukan hanya pembentukan keluarga baru, tetapi juga ikatan dua keluarga besar yang bisa berbeda dalam segala hal: sosial, ekonomi, dan budaya.

Meskipun budaya Barat telah merambah setiap aspek kehidupan masyarakat, pesta pernikahan tradisional tampaknya semakin populer. gedung konferensi. Ini akan tergantung pada pilihan pihak untuk menjadi tuan rumah perayaan pernikahan. Prosesi pernikahan adat boleh dilakukan seluruhnya atau seluruhnya, tetapi hanya sebagian yang boleh dipimpin tergantung dari kemampuan pihak yang memimpin prosesi pernikahan adat. Bentuk kebhinekaan berarti berkomunikasi dan saling mengenal, yang berujung pada tegaknya pernikahan, pendahulu keluarga.
Keluarga merupakan unit terkecil dari masyarakat atau bangsa. Akibatnya, kehidupan sehari-hari memiliki budaya atau tradisi yang berbeda dari setiap kelompok sosial. Setiap kelompok sosial memiliki lingkungan sosialnya masingmasing, yang diturunkan secara turun temurun dari nenek moyang sebelumnya. Oleh karena itu, tidak heran jika saat ini kita dihadapkan pada adat dan budaya yang berbeda ketika kita merayakan atau menyambut pernikahan, salah satu peristiwa terpenting dalam kehidupan nusantara.

Pernikahan merupakan peristiwa yang sangat penting dan memiliki makna yang sangat sakral. Melalui perkawinan, seseorang dibebaskan dari lingkungan keluarga dan mulai membentuk keluarga baru. Karena momen pernikahan begitu penting, semua orang ingin merayakan momen ini dengan upacara yang sangat sakral dan meriah yang biasanya melibatkan kerabat dan elemen sosial lainnya.

Adat adalah gagasan kebudayaan yang terdiri dari nilai-nilai kebudayaan, norma, kebiasaan, kelembagaan, dan hukum adat yang lazim dilakukan di suatu daerah. Apabila adat ini tidak dilaksanakan akan terjadi kerancuan yang menimbulkan sanksi tak tertulis oleh masyarakat setempat terhadap pelaku yang dianggap menyimpang, sama halnya dengan peristilahan adat pernikahan pada masyarakat Madura di Wajok Hilir yang menggunakan atau memberikan khas tertentu pada masing-masing daerah mengenai adat yang ada pada daerah tersebut. Adat istiadat tidak terlepas juga dengan masyarakat Madura yang ada pada Wajok Hilir beragam peninggalan adat istiadat yang masih dipegang teguh oleh masyarakat masih tetap terjaga sampai sekarang.

Beragam jenis peristilah adat pernikahan yang masih dipegang teguh dan 
masih dijalankan oleh masyarakat Madura Wajok Hilir peristilahan adat pernikahan yang paling menarik untuk dibahas lebih lanjut adalah adat pernikahan masyarakat Madura Wajok Hilir dalam pelaksanaan adat perkawinan ini terdapat beberapa macam tahapan prapernikahan, pelaksanaan pernikahan, dan pascapernikahan.

Tahapan yang dimaksud yaitu, ngangene, araba pagar, nyabe'jajan (alamar), teket petton, nyedek temo, cenglancengan, telo areh, petong are yang merupakan satu kesatuan prapernikahan dan pascapernikahan.

Selain tahapan tersebut, yang menarik untuk diketahui yaituterdapat pula berbagai alat yang dipakai dalam pelaksanaan acara pernikahan.Peralatan tradisional tersebut berupa wujud benda dalam bentuk barang pelengkap adat pernikahan. Peralatan tersebut merupakan satuan media pokok dalam pelaksanaan upacara pernikahan seperti ritual adat, yaitu becen, cobik dan menggunakan berbagai makanan trasional masyarakat Madura yang harus ada pada saat acara tersebut dilaksnakan.

Makanan khas wilayah merupakan santapan yang biasa di konsumsi di suatu daerah, dengan bermacam- macam serta bervariasinya bahan dasar, hingga bisa dihasilkan beragam tipe makanan tradisional yang dipunyai oleh warga Madura sepeti, cucur, bejit, kettel, dodol sedemikian rupa sehingga jadi santapan yang lezat serta gizi balance. Santapan ini ialah salah satu santapan yang turut temurun yang diadakan pada kegiatan tertentu, semacam kegiatan perkawinan bulan rebbe yang wajib terdapat pada dikala kegiatan tersebut dengan tujuan buat melestarikan santapan tradisional yang dipunyai oleh warga Madura.

Tahapan mengenai hari untuk pelaksanaan pernikahan tersebut ada hari yang harus dilakukan pada masyarakat
Madura. Hari perikahan tersebut yaitu sebagai berikut. Pertama, Senin pon (pakse) dalam artian berharap pernikahan tersebut akan berlangsung lama tidak ada peceraian yang akan terjadi pada penganten tersebut. Kedua, selasa pon (lakonnah kunung) berharap dalam pernikahan tersebut mereka menjadi keluarga yang besar dan mampu menyelesaikan masalah seperti besarnya gunung. Ketiga, rabu pon (lakonnah bintang) berharap dalam pernikahan tersebut agar cerah bagaikan bintang yang selalu cerah dimalam hari. Hal ini merupakan suatu bentuk pelestarian adat istiadat yang masih terjaga oleh masyarakat setempat.

\section{METODE PENELITIAN}

Metode yang digunakan peneliti dalam penelitian ini adalah metode deskriptif. Data yang diperoleh peneliti berupa kata-kata, kemudian dari hasil yang telah dianalisis peneliti menyajikannya melalui kata-kata dan kalimat dan bukan berupa angka atau melakukan perhitungan.

Moleong (2017:11) mengatakan bahwa dengan menggunakan metode deskriptif data yang dikumpulkan berupa fakta gambar dan bukan angka sehingga laporan penelitian akan mengutip kutipan dan memerikan gamaran tentang penyajian laporan.

\section{Bentuk Penelitian}

Bentuk penelitian ini adalah penelitian kualitatif. Peneliti memilih bentuk penelitian kualitatif karena peneliti memfokuskan pada subjek yang diteliti sehingga subjek yang diperoleh berupa data tentang apa yang telah dialami dan peristiwa yang pernah terjadi di lingkungannya.

Moleong (2017:56 ) mengatakan bahwa penelitian kualitatif adalah penelitian yang bertujuan untuk menemukan memahami dan memahami fenomena tentang apa yang dialami oleh 
subjek penelitian misalnya perilaku persepsi motif tindakan dan lain-lain dalam entuk deskripsi veral dan linguistik.

\section{Sumber Data dan Data}

Sumber informasi merupakan sesuatu yang sangat berarti dalam riset. Sumber riset merupakan subjek serta dari mana informasi diperoleh. Menurut Idrus( 2009: 93), pembicaraan tentang subjek periset hendak dengan sendirinya menyangkut populasi serta ilustrasi riset, dengan kalimat lain, penentuan subjek riset bisa dicoba dengan metode populasi serta ilustrasi.

Metode populasi dicoba apabila pengambilan subjek riset meliputi totalitas populasi yang terdapat. Sedangkan itu, metode ilustrasi merupakan pengambilan subjek riset dengan metode memakai sebagian dari populasi yang terdapat.

Pada dasarnya pemakaian ilustrasi riset diperkenankan dalam presedur riset sepanjang ilustrasi tersebut bisa mewakili populasinya secara baik( representatif) dan memakai metode pengambilan ilustrasi( metode sampling) yang benar.

Sumber informasi dalam riset ini merupakan sesepuh, penghulu, danpengantin yang ikut serta dalam prosesi penerapan perkawinan adat Madura. Informan dalam riset ini diseleksi bersumber pada criteria tertentu supaya informasi yang diperoleh lebih valid.

Mahsun( 2007: 141), selaku sumber data serta sekalian bahasa yang digunakan itu mewakili bahasa kelompok penutur di wilayah pengamatanya tiap- tiap, hingga pemilihan seorang buat dijadikan informan.

Informasi merupakan suatu yang nyata, cocok apa yang terdapat di lapangan, cocok apa yang betul- betul terjalin. Informasi dalam riset ini merupakan seluruh peristilahan yang ada dalam adat perkawinan warga Madura, bahan, perlengkapan serta prosesnya. Informasi yang didapatkan dalam riset buat kasus satu, kedua serta ketiga ini merupakan perkata.

\section{Teknik dan Alat Pengumpulan Data}

Teknik dalam penelitian ini menggunakan dua teknik yaitu teknik catat dan teknik wawancara, teknik catat di peroleh dari ungkapan informan masyarakat Madura di Wajok Hilir dan teknik wawancara bertujuan untuk memperoleh data lingual yang dituturkan oleh informan dalam pelafalan nama-nama, alat dan bahan yang digunakan dalam adat pernikahan masyarakat Madura di Wajok Hilir.

\section{Teknik Catat}

digunakan untuk menginfertarisasi kata-kata ataupun kalimat yang disampaikan oleh informan mengenai aktifitas adat pernikahan masyarakat Madura di Wajok Hilir. Teknik wawancara bertujuan untuk memacing informan berbicara sehingga peneliti memperoleh data tambahan berkaitan dengan istilah dari aktifitas adat, alat dan bahan yang digunakan dalam adat pernikahan masyarakat Madura di Wajok Hilir, Kabupaten Mempawah.

Pengumpulan datanya yaitu dengan cara melakukan observasi pada saat acara perkawinan di Wajok Hilir, kemudian menanyakan tentang tahapan adat yang dilakukan dalam adat pernikahan masyarakat Madura di Wajok Hilir dan merekamnya. Kemudian peneliti mengumpulkan data dengan cara menulis dan merekam tuturan informan tentang adat perkawinan masyarakat Madura di Wajok Hilir Kabupaten Mempawah.

\section{Alat Pengumpulan Data}

Alat pengumpulan data dalam penelitian ini adalah peneliti sendiri sebagai instrumen kunci dalam penelitian ini. Untuk mempermudah peneliti melakukan 
penelitian di lapangan, peneliti menggunakan alat pengumpulan data sebagai pedoman wawancara, buku catatan, alat tulis, kamera, serta alam perekam suara.

Langkah-langkah pengumpulan data dalam penelitian ini sebagai berikut:

1. Peneliti bertemu dengan informan

2. Peneliti mewawancarai informan yang berkaitan dengan peristilahan pernikahan tradisi masyarakat Madura di Wajok Hilir Dusun Coklat Kecamatan Siantan Kabupaten Mempawah menggunakan daftar pertanyaan yang sudah disiapkan.

3. Peneliti mencatat, merekam pembicaraan informan.

4. Peneliti mentraskrip hasil wawancara dengan informan.

5. Peneliti menerjemahkan data yang diperoleh dalam bahasa Madura dalam bentuk bahasa Indonesia.

\section{Teknik Analisis DataTranskripsi}

Peneliti mengubah hasil wawancara ke dalam bentuk tulisan agar lebih mudah diteliti. Data yang diperoleh dari hasil pengumpulan data , mulai dipilih sesuai dengan pembahasan peristilah adat pernikahan pada masyarakat Madura di Mempawah.

\section{Klarifikasi Dan Verivikasi Data}

Data yang dikumpulkan kemudian diklarifikasikan atau pengelompokan data yang diperiksa mengenai kebenaran datanya sesuai sub-sub masalah apa yang peneliti teliti, kemudian ditransipkan data dan mencatat agar lebih mudah dianalisis.

\section{Penganalisisan}

Data yang dianalisis ialah kegiatan tahapan adat pernikahan, dari prapernikahan, pelaksanaan prapernikahan sampai pascapernikahan, menganalisis satuan bentuk lingual arti, dan akan merancang rencana pelaksanaan pembelajaran dan suplemen teks tentang peristilahan adat pernikahan pada masyarakat Madura di Mempawah sebagai implikasi penelitian terhadap pembelajaran Bahasa Indonesia.

Teknik analisis data yang dilakukan agar tujuan penelitian dapat tercapai dengan baik, maka harus ada perencaan dan persiapan yang sistematis. Untuk menganalisis data peristilahan proses pernikahan dalam tradisi masyarakat Madura. Teknik analisis data dilakukan dengan langkah-langkah sebagai berikut.

a. Membaca kembali data yang sudah ada dan sudah diklafikasikan.

b. Menganalisis, mentranskripsikan dan menginterpresetasikan bentuk berdasarkan peristilahan adat pernikahan pada masyarakat Madura di Wajok Hilir Kabupaten Mempawah.

c. Menganalisis, mentranskripsikan dan menginterpresetasikan makna berdasarkan peristilahan adat pernikahan pada masyarakat Madura di Wajok Hilir Kabupaten Mempawah.

d. Menyimpulkan secara keseluruhan mengenai data yang diperoleh guna menghasilkan gambaran linguistik secara menyeluruh tentang peristilahan adat pernikahan masyarakat Madura di Wajok Hilir Kabupaten Mempawah.

\section{HASIL PENELITIAN DAN PEMBAHASAN HASIL}

Sehubungan dengan permasalahan yang ada pada penelitian ini, maka analisis data yang akan dipaparkan oleh peneliti dalam penelitian ini yaitu mendeskripsikan prosesi adat istiadat pernikahan masyarakat Madura di Wajok Hilir Kabupaten Mempawah, bentuk satuan lingual, arti leksikal, dan arti kultural.

Ketiga submasalah tersebut dianalisis berdasarkan data yang telah dikumpulkan dari peristilahan adat istiadat pernikahan masyarakat Madura di Wajok Hilir, Kabupaten Mempawah, Keselurahan data peristilahan dalam penelitian ini akan dipaparkan dalam bentuk deskripsi dan tabel data yang dilengkapi dengan lambang 
fonetik, definisi masyarakat, dan definisi bahasa Indonesia.

Pembahasan

Data lapangan yang diperoleh peneliti merupakan data yang dihimpun dari proses penelitian lapangan yang dilakukan masyarakat Wajok Hilir.

Deskripsi Prosesi Adat Pernikahan Masyarakat Madura di Wajok Hilir, Kabupaten Mempawah dari Prapernikah, Pelaksanaan Pernikahan sampai Pascapernikahan. Adat istiadat dan aturanaturan yang berlaku dalam masyarakat tidak terlepas dari pengaruh budaya dan lingkungan yang ada dalam masyarakat tersebut. Hal tersebut bisa dipengaruhi oleh tingkat pendidikan, kepercayaan, pengalaman, kebiasaan, serta agama yang dianut oleh masyarakat tidak terkecuali masyarakat Madura. Aturan-aturan dan upacara adat pernikahan masyarakat Madura yang ada merupakan warisan turun temurun dari nenek moyang yang dilaksanakan apabila akan dilaksanakan pernikahan. Prosesi tersebut sudah menjadi tradisi yang terus dilestarikan dan tidak bisa lepas dari ruang lingkup pernikahan yang dilaksanakan oleh masyarakat Madura.

Rangkaian prosesi dalam adat pernikahan masyarakat Madura tidak hanya tergolong unik, dalam perayaan dan penyuguhan makanan juga sangat mewah tanpa membedakan status sosial keluarga yang bersangkutan. Adat pernikahan yang dilaksanakan pada masyarakat Madura Mempawah khususnya masyarakat Madura yang terdapat di Desa Wajok Hilir memiliki tiga prosesi pernikahan, mulai dari proses prapernikahan, pelaksanaan pernikahan, dan pasca pernikahan.

\section{Prosesi Prapernikahan.}

Prosesi prapernikahan yang dilaksanakan dalam pernikahan masyarakat Madura di Desa Wajok Hilir terdiri atas beberapa tahap, sebagai berikut.

\section{Ngangene}

Ngangene merupakan tahap pertama dalam prosesi prapernikahan yang dilakukan pihak keluarga yang akan melaksanakan acara pernikahan. Ngangene yang sering diistilahkan masyarakat Madura dengan istilah memberi angin atau memberi kabar. Hal tersebut artinya tradisi prapernikahan dimulai dari tahap penjajakan yang disebut sebagai ngangene, prosesi ini dilaksankan sebagai tolak ukur sejauh mana kemungkinan pihak pria bisa diterima oleh keluarga pihak wanita. Bagi masyarakat Madura yang menjadi bahan pertimbangan pertama agar bisa diterima dilihat dari segi agamanya. Hal tersebut dikarenakan masyarakat Madura tergolong sangat taat pada ajaran agama. Setelah terjadi kesepakatan antara keluarga lanceng (pejaka) dan keluarga praben (gadis), maka tahapan ngangene (penjajakan) selesai dilaksanakan.

\section{Arabe Pager}

Arabe pager adalah membabat pagar atau perkenalan antara orang tua, pertemuan kedua keluarga calon mempelai sebagai perkenalan. Pada momen ini, ada tradisi ater tolo, yaitu keluarga mempelai pria membawakan kosmetik, beras dan pakaian adat Madura untuk mempelai wanita. Kemudian kedua keluarga mengadakan nyedek temo, yakni penentuan hari dan tanggal pernikahan. Seminggu setelahnya, keluarga perempuan membalas kedatangan keluarga calon mempelai pria dengan membawa hidangan nasi lengkap dengan lauk-pauknya.

\section{Nyabe' Jajan}

Nyabe' jajan merupakan tahap lanjutan dari araba paker. Nyabe' jajan adalah lamaran yang dilakukan sebelum perkawinan dilaksanakan. Pihak laki-laki mengadakan lamaran (peminta) dengan mempersiapkan alat-alat untuk lamaran berupa; (1) sapu tangan, (2) minyak wangi, dan (3) uang sesuai kehendak pihak lakilaki. Ketiga alat tersebut diserahkan secara langsung oleh ketua yang ditunjuk oleh pihak laki-laki. Alat-alat tersebut sebagai 
bukti bahwa seorang perempuan telah resmi bertunangan dan harus menjaga status tersebut dengan baik dan bertanggungjawab hingga pernikahan dilaksanakan.

\section{Teket Petton}

Teket petton merupakan tahap penyerahan perlengkapan lamaran pada pihak praben (gadis). Tahap penyerahan perlengkapan lamaran ini dilaksanakan sesuai kehendak yang dilakukan oleh pihak laki-laki. Alat-alat (perlengkapan) yang diserahkan berupa; (1) kocor (cucur), (2) polot (ketan) yang sudah dimasak, (3) sirih dan pinang, (4) serta (4) pakaian lengkap perempuan, seperti sarung, todung, kelampih, alat-alat perhiasan.

\section{Nyedek Temo}

Nyedek Temo merupakan tahap perancangan menentukan hari perkawinan. Setelah proses lamaran maka kedua belah pihak kembali bertemu untuk menentukan waktu pelaksanaan pernikahan. Kebiasaan pada Masyarakat Madura khususnya masyarakat Desa Kacang Wajok Hilir, apabila perknikahan ingin dipercepat, biasanya pihak laki-laki datang dengan membawa perlengkapan-perlengkapan sebagai tanda acara pernikahan akan dipercepat. Perlengkapan itu berupa pisang susu yang sering disebut kesusu, sirih dan pinang, seperangkat pakaian, serta ikat pinggang (stagen) yang berarti pengikat.

\section{Prosesi Pelaksanaan Pernikahan}

Prosesi pelaksanaan pernikahan merupakan proses yang menjadi inti dari prosesi adat pernikahan masyarakat Madura. Proses pelaksanaan pernikahan pada masyarakat Madura di Desa Kacang, Wajok Hilir terdiri atas beberapa aktivitas. Aktivitas tersebut berupa arepbe, beres koning, akad, dan serah teremah antaran.

\section{Arepbe}

Arepbe merupakan aktivitas selamatan yang dilakukan oleh pihak mempelai laki-laki atau pun pihak mempelai perempuan dengan tujuan untuk keselamatan dalam proses pernikahan. Masyarakat Madura sering menyebut aktivitas ini dengan istilah tacin atau nasi slametan. Biasanya nasi tacin ini diberikan dengan mengadakan suatu pengajian atau yang sering disebut sebagai slametan.

Slametan sendiri merupakan bentuk rasa syukur atau doa bagi mereka yang merayakannya. Slametan pada masyarakat Madura dilaksanakan tidak hanya dalam prosesi adat pernikahan tetapi dalam presosi lain seperti memperingati hari lahir atau hal-hal berbahagia yang lain.Upacara selamatan merupakan salah satu bentuk adat istiadat yang dianggap dapat menjauhkan diri dari mala petaka baik selama proses pelaksanaan acara adat maupun setelahnya.

\section{Beres Koning}

Beres koning merupakan aktivitas menyebar beras kuning. Tradisi tersebut menjadi salah satu kebiasaan Masyarakat Madura. Tradisi adat ini menjadi salah satu bentuk yang harus dilakukan dalam pernikahan, pada saat mempelai pengantin laki-laki hendak keluar dari rumah dan pergi menyunting mempelai perempuan menjadi istri. Beras kuning tersebut dilempar ke mempelai pengatin lelaki pada saat berjalan keluar rumah. Hal tersebut dilakukan dengan tujuan untuk keselamatan dalam perjalanan menujut empat pelaksanaan pernikahan.

\section{Akad}

Akad merupakan puncak dari acara yang menjadi proses awal kehidupan baru bagi kedua mempelai dalam membina rumah tangga. Akad merupakan pengikat perjanjian yang sangat sakral yang dilakukan mempelai laki-laki kepada wali nikah mempelai perempuan biasanya ayah atau saudara laki-laki kandung dari mempelai perempuan tersebut. Akad ini 
menjadiinti acara yang menentukan sahnya kedua mempelai menjadi pasangan suami istri.

Pada saat proses akad mempelai laki-laki diwajibkan membawa dua belas leppet(kue yang dibungkus daun pisang) untuk dimakan setelah akad berlangsung.

\section{Serah Teremah Antaran}

Serah teremah antaran merupakan aktivitas atau tradisi yang sudah tidak asing lagi dilaksanakan setelah akad dilaksanakan baik masyarakat Madura maupun tradisi masyarakat lain. Calon mempelai laki-laki harus memberi hantaran barang kepada calon mempelai perempuan, hantaran tersebut biasanya berupa keperluan perempuan seperti; alat hias, cincin, mahar, dan sejumlah uang.

Keunikan yang terjadi pada adat perknikahan masyarakat Melayu Pontianak di kelurahan Batu layang ialah mempelai perempuan juga member hantaran tanda terima kasih namun hantaran tersebut berupa kue dan satu paket kapur sirih sebagai syarat, tidak berbentuk barang dan yang lainnya. Kue hantaran tersebut ialah bingka, kue tar, kue lapes dan lain-lain.

\section{Prosesi Pasca pernikahan}

Pasca pernikahan merupakan proses terakhir dari rangkaian acara yang dilaksanakan oleh masyarakat Madura. Prosesi pascapernikahan masyarakat Madura terdiri dari dua rangkaian prosesi adat yang harus dijalankan oleh kedua mempelai yang telah sah menjadi suami istri. Prosesi adat tersebut yaitu ceng lanceng.

\section{Ceng Lanceng}

Ceng lanceng (silaturahmi dari pihak mempelai perempuan ke rumah mempelai laki-laki) merupakan prosesi adat yang harus dilaksanakan setelah kedua mempelai pengantin melakukan proses pernikahan. Ceng-lanceng dilakukan tiga atau tujuh hari setelah acara pernikahan dilaksanakan. Adat ceng-lanceng ini dihadiri oleh para sesepuh, sanak keluarga dan tetangga sekitar. Bebarapa benda dan alat yang harus ada dalam adat ceng lanceng ialah cucur, ketel, dan polot.

Rangkaian prosesi adat ceng lanceng pengantin di Wajok Hilir dimulai dengan melakukan selametan dengan menyediakan tacin poteh (nasi putuh) yang sudah dibacakan doa oleh ustad. Setelah itu tacin poteh dimakan para pengantin wanita yang hendak untuk pergi beserta rombongannya, Adat ini dilakukan oleh sanak keluarga yang dianggap tua. Orang yang melakukannya diawali dengan yang paling tua terlebih dahulu yaitu nenek dan kakek dari kedua pengantin kemudian orang tuanya lalu sanak keluarga yang dianggap tua.

Berdasarkan pemaparan tersebut dapat disimpulkan bahwa prosesi adat pernikahan masyarakat Madura di Mempawah terdapat tiga proses. Pertama, prosesi prapernikahan yang meliputi proses arabe pagar, nyabe' jajan, tekenpetton, dan nyedektemo. Kedua, prosesi pelaksanaan pernikahan yang meliputi proses arepbe, bereskoneng, akad, dan serah terema hantaran. Ketiga, prosesi pasca pernikahan meliputi proses ceng lanceng.

\section{SIMPULAN DAN SARAN Simpulan}

Penelitian terhadap Peristilahan Adat Pernikahan Masyarakat Madura di Mempawah yang terdapat di DesaWajokHilir memiliki tiga prosesi adat yang harus dijalani oleh kedua mempelai beserta keluarga. Pertama, prosesi prapernikahan yang terdiri dari lima proses adat yang harus dilaksanakan yaitu; (1) ngangane, (2) arabe pagar, (3) nyabe' jajan, (4) teket petton, dan (5) nyedek temo. Setelah melaksanakan ritual-ritual atau tradisi adat prapernikahan prosesi kedua 
dilanjutkan dengan prosesi pelaksanaan pernikahan.

Dalam prosesi pelaksanaan pernikahan ada empat prosesi adat yang harus dijalani kedua mempelai yaitu; (1) arepbe, (2) beres koneng, (3) akad, dan (4) serah teremah antaran. Kemudian prosesi yang ketiga atau terakhir yaitu prosesi pascapernikahan. Dalam prosesi pascapernikahan kedua mempelai diharuskan melaksanakan ritual adat ceng lanceng, ritual tersebut adalah ritual penutup. Pada ritual ceng lanceng kedua mempelai menjalankan prosesi slametan atau selamatan atas pernikahan yang telah dilaksanakan dan berharap pernikahan tersebut bisa mendapat keselamatan dan kebahagiaan dalam membina rumah tangga.

\section{Saran}

Berdasarkan penelitian dan hasil analisis peneliti terhadap peristilahan adat pernikahan masyarakat Madura di Mempawah, peneliti memberikan beberapa saran sebagai berikut.

Kajian peristilahan dalam adat pernikahan masyarakat Madura, sangat menarik untuk dianalisis. Peneliti berharap, penelitian selanjutnya dapat meneruskan dan mempertahankan keutuhan adat dan kebudayaan yang masih sangat kental akan tradisi dan kebiasaan yang diturunkan oleh nenek moyang.

\section{DAFTAR RUJUKAN}

Abdullah, Wakit. 2014. Etnolinguistik: Teori, Metode, dan Aplikasinya. Universitas Sebelas Maret Surakarta: Jurusan Sastra Daerah Fakultas Sastra dan Seni Rupa.

Aminuddin. 1988. Semantik, Pengantar Studi Tentang Makna. Bandung: CV Sinar Baru.
Arifin, E. Zaenal. 2013. Semantik BahasaIndonesia. Jakarta: Pustaka Mandiri.

Chaer, Abdul. 2009. Pengantar Semantik Bahasa Indonesia. Jakarta: RinekaCipta.

Chaer, abdul. 2003. Linguistik Umum. Jakarta: Renika Cipta.

Djajasudarma, Fatimah. 2013. Semantik 2 Relasi Makna dan Pragdimatik, sintakmatik, dan Derivasional. Bandung: PT Refika Aditama.

Djajasudarma, T. Fatimah. 1993. Metode Linguistik: Ancangan Metode Penelitian dan Kajian. Bandung: PT Eresco.

Hashimah Jalaluddin, Nor. 1992. Semantik dan Pragmatik. Malaysia: Dewan Bahasa dan Pustaka.

Idrus, Muhammad. 2009. Metode Penelitian Ilmu Sosial. Yogyakarta: Erlangga.

Kamus Besar Bahasa Indonesia.2008. Edisi Keempat. Jakarta : Gramedia Pustaka Utama.

Kridalaksana, Harimurti. 2011. Kamus Linguistik. Jakarta: PT Gramedia Putaka Utama.

Lyons. John. 1997. Kamus Linguistik. Jakarta: PT Gramedia Pustaka Utama.

Mahsun. 2014. Metode Penelitian Bahasa. Jakarta: PT Raja Grafindo Persada.

Moleong, Lexy J. 2017. Metode Penelitian Kualitatif. Bandung: Remaja Rosdakarya.

Sudarjat, Yayat. 2006. Makna Dalam Wacana (Prinsip-Prinsip Semantik dan Pragmatik). Bandung: CV RAMA WIDYA.

Sudaryanto.1993. Metode danAneka TeknikAnalisisBahasa (Pengantar 
Penelitian Wahana Kebudayaan secaraLinguistik). Yogyakarta:Duta Wacana University Press. 